\title{
Konsep Diri Dan Tingkat Burnout Pada Karyawan Yang Bekerja Di Instansi Pelayanan Masyarakat
}

\author{
Rina Amelia \\ Zulkarnain \\ Program Studi Psikologi \\ Fakultas Kedokteran \\ Universitas Sumatera Utara
}

\begin{abstract}
The aim of this study is to imestigate the relationship between Self concept and Bumout. The study was a field research with data collected through Scale of Self Concept and Scale of Bumout. The subject were emplayees of one public service in Medan. The number of subject was 85 . The result show that there was a negative correlation between self concept and bumout $\left(r_{x y}=-0.583, p<0.01\right)$. Self Concept contributes $34 \%$ to Burnout. in addition, the finding also shows there was a significant difference in bumout based on worked period ( $F=3.431, p<$ 0.05 ). Employees who have worked period of $11-20$ years, shows more significant tendency to bumout than employees who have worked period of 2.10 years and $21-28$ years.
\end{abstract}

Keywords : Self Concept, Burnout.

\section{Pendehuluan}

S alah satu persoalan yang muncul karena tekanan akibat meningkatnya tuntutan kerja dan persaingan yang keras di tempat kerja ialah stres. Stres merupakan salah satu bentuk gangguan jiwa yang banyak dialami oleh anggota masyarakal angkatan kerja. Stres dapa! berupa kelegangan mental yang mengganggu kondisi emosional, proses berfikir dan kondisi fisik seseorang.

Data mengenai stres keria di Indonesia belum begitu banyak diketahui. Prawitasari (dalam Farhati \& Fosyid, 1996) memperkirakan) bahwa stres kerja di Indonesia akan terus meningkat sejalan dengan perkembangan zaman. Stres yang dialami individu dapat terjadi dakan jangka waktu yang berbedabeda.
Permasalahan akan muncul bilamana stres terja dalam jangka waktu yang lama dengan intensitas yang cukup linggl. Sebagai akibatnya individu akan mengalami kelelahan fisik maupun mental. Keadaan ini disebut bumout, yaitu kelelahan fisik, mental, dan emosional yang terjadi karena stres yang diderita dalam jangka waktu cukup lama, didalam situasi yang menuntut keterlibatan emosional yang tinggi (Leatz \& Stolar, 1993).

Berdasarkan survey dari CareerBuilder.com bahwa 68 persen dari pekerja dilaporkan merasakan burnout di tempal kerianya (Lorenz, 2004). Beberapa penelitian membuktikan bahwa stres dan bumout adalah berbeda. Bumout lebih dari pada 
stres. Individu yang tidak pernah mengharapkan apa-apa dari pekerjaannya tetapi ketika harus membayar lebih untuk pekerjaannya dapat mengalami stres kerja, tapi beium tentu burnout. Bumout merupakan suatu kondisi yang mempengaruhi individu yang termotivasi dengan idealisasi yang tinggi (Staniey, 2004).

Burnout pada dasarnya bukan suatu gejaia dari stres kerja, tetapi merupakan hasil dari stres kerja yang tidak dapat dikendalikan dan merupakan suatu keadaan yang serius (Staniey, 2004). Jadi, bumou'merupakan suau respon terhadap kondisi kerja yang stres. Beberapa peneiitian juga menunjukkan bahwa pekerja human servicemengalami bumoutdalam merespon terhadap stes keja (Berry, 1998).

Seperti yang dikemukakan oleh Pines dan Aronson (dalam Farhati \& Rosyid 1996) yang menyatakan bahwa burnout adaiah suatu bentuk ketegangan atau tekanan psikis yang berhubungan dengan stres kronik, dialami seseorang dari hari ke hari, ditandai dengan keieiahan fisik, mental dan emosional.

Masclach (dalam Schaufeli \& Buunk, 1996) memberikan gambaran adanya tiga dimensi bumout, yaitu: a) keielahan emosional yang ditandai dengan perasaan frustrasi, putus asa, sedih, tidak berdaya, tertekan, dan la merasa terjebak Ditambah mudah tersinggung dan marah tanpa aiasan yang jelas; b) depersonalisasi, ditandaj dengan menjauhnya individu dari tingkungan sosial, apatis, tidak peduli terhadap lingkungan dan orang-orang disekitarnya; c) rendahnya penghargaan terhadap diri sendiri, yaitu individu tidak pernah merasa puas dengan hasii karyanya sendiri, merasa tidak pernah melakukan sesuatu yang bermanfaat bagi diri sendiri maupun orang lain.

Peneiitian yang dilakukan oieh Freudenberger dan Richeison (dalam Farhatl \&. Rosyid, 1996) menemukan bahwa hampir semuapenderita bumoutpada mulanya adalah orang-orang yang bersemangat, energik, optimistik, dan memiliki prinsip yang kuat, serta mau bekerja keras untuk merah prestasi. Mereka tidak mengenal istiah gagal.

Golembiewsky, Hilles dan Daiy (1987) menyatakan aklbat dari bumoutdapat muncul dalam bentuk berkurangnya kepuasan kerja meningkatnya stres kerja, partisipasi menurun, ketelitian berkurang, memburuknya performance, produktifitas rendah, dan meningkatnya gangguan fisik dan mental pada diri karyawan. Bila hal ini terjadi pada karyawan tentu saja akan mempengauhi perf ormanceperusahaan.

Ada 2 hai utama yang memungkinkan seseorang mengabmi bumout Jackson, Schuler dan Schwab (1986) mengatakan bahwa bumout terjadi karena adanyakesenjangan antaraharapan dan kenyataan yang dialami seseorang ditempat kerja. Keserjangan harapan dan kenyataen yang dimaksud adalah harapan tentang prestasi yang seharusnya dicapai dan unjuk kerja yang dimiliki. Kesenjangan lainnya terjad bilaorganisasi tempat bekerja seseorang tidak sesuai dengan harapan atau tata nilai pribadinya.

Berdasarkan perspektif teori belajar, bumout merupakan hasil dari pengharapan yang salah terhadap reinforcement, outcome, dan efficacy(Schaufeli \& Buunk, 1996). Dalam hal int pekerja meietakkan standar keberhasilan pribadi yang terlalu tinggi yang sulit dicapai berdasarkan kemampuan yang dimilikinya.

Tingginya standar keberhasilan pribadi berkaitan dengan konsep diri. Konsep diri merupakan hai yang penting artinya bagi kehidupan individu karena pemahaman mengenai konsep diri akan menentukan dan mengarahkan perilaku dalam berbagai situasi serta menentukan keberhasilan individu daiam hubungannya dengan masyarakat (Shavelson dalam Meilaratri \& Zuikarnain, 2004)

Menurut Caihoun dan Acoceila (1995) konsep diri adalah pandangan pribadi individu terhadap dirinya yang meliputi tiga dimensi, yaitu pengetahuaan tentang diri, pengharapan mengenai diri dan penilajan tentang diri sendiri.

Dimensi pertama dari konsep diri adalah apa yang individu ketahuil tentang diri sendiri. Dalam benak individu ada satu daftar juiukan yang menggambarkan tentang dirinya: usia, jenis kelamin, kebangsaan, suku, pekerjaan, dan lain sebagainya. Dimensi kedua dari konsep diri adalah pengharapan mengenai diri. Pada saat individu mempunyai satu set pandangan lain yaitu tentang kemungkinan 
individu menjadi apa dimasa mendatang. Pendeknya, individu mempunyai pengharapan bagi dirinya sendiri. Dimensi ketiga konsep diri adalah penilaian terhadap dri sendiri. Individu berkedudukan sebagai penilai tentang dirinya sendiri setiap hari, mengukur apakah individu bertentangan dengan pengharapannya bag diti sendiri dan standar individu bagi dirinya sendiri (Calhoun \&Acocella, 1995).

Maslach (dalam Sutjipto, 2001) mengatakan bahwa individu yang memiliki konsep diri rendah atau negatif lebih rentan terhadap bumout la menggambarkan bahwa karakteristik individu yang memiliki konsep diri rendah yaitu tidak percaya diri dan memiliki penghargaan diri yang rendah. Mereka pada umumya dilingkupi oleh rasa takut sehingga menimbulkan sikap pasrah. Dalam bekerja, mereka tidak yakin sehingga menimbulkan beban kerja berlebhan yang berdampak pada terkurasnya sumber diri. Penilaian diri yang negatif ini menyebabkan mereka lebih menitikberatkan perhatian pada kegagalan dalam setiap hal sehingga menyebabkan perasaan tidak berdaya dan apatis.

Menurut Calhoun dan Acocolla (1995) ada dua jenis konsep diri negatif. Satu, pandangan seseorang tentang dirinya sendiri benar-benar tidak teratur: individu tidak memiliki perasaan kestabilan dan keutuhan diri. Individu benar. benar tidak tahu siapa dirinya, ape kekuatan dan kelemahannya, atau apa yang dihargai dalam hidupnya. Kodua, pandangan terhadap diri yang terlalu stabi dan terlalu teratur, dengan kata lain, kaku. Mungkin karena didikan dengan sangat keras, individu tersebut menciptakan citra-diri yang tidak mengizinkan adanya penyimpangan dari seperangkat hukum besi yang dalam pikirannya merupakan cara hid up yang tepat.

Dalam kaitannya dengan evaluasi diri, konsep diri yang negatif menu rut defenisinya meliputi penilaian yang negatif terhadap diri. Dalam kaitannya dengan harapan orang dengan konsep diri negatif, bahwa mereka percaya kalau dirinya tidak dapat mencapai suatu apapun yang berharga, orang tersebut merancang pengharapannya sedemikian rupa sehingga dalam kenyataan ia tidak mencapai suatu apapun yang berharga (Calhoun \& Acocella, 1995).

Dasar dari konsep diri yang positif bukanlah kebanggaan yang besar tentang diri totapi lebih berupa penerimaan diri. Kualitas ini lebih mungkin mengarah pada kerendahan hati dan kedermawanan daripada keangkuhan dan egois. Tidak seperti konsep diri negatif yang terlalu kaku atau terlalu longgar, konsep diri positif bersifat stabil dan bervariasl. Jadi, orang dengan konsep diri positif dapat memahami dan menerima sejumlah takta yang sangat bermacam-macam tentang dirinya (Calhoun \&Acocella, 1995).

Konsep diri yang positif itu cukup luas untuk menampung seluruh pengalaman mental seseorang evaluasi tentang dirinya senoiri menjadi positif. individu dapat menerima dirinya sendiri secara apa adanya dan diajuga dapat menerima orang lain. Mengenai pengherapan, individu dengan konsep diri positif merancang tujuan-tujuan yang sosuai dan realstis (Cahoun \&Acocella, 1995).

Apabila setiap karyawan dalam suatu organisasi atau suatu perusahaan merasakan bahwa prinsip dan nilaiñnilai yang mendasari tindakan dan perilaku perusahaan sesuai dengan pandangan hidupnya, tidak menyimpang dari prinsip pribadinya, maka karyawan terse but akan bekerja dengan baik. Apu la ji jika mereka memahami maksud, bujuan dan -uang lingkup kegiatan perusahaan serta mereka merasakan bahwa pandangan hiduprya atau citañcitanya akan mendapat tempat yang sesuaj di perusahaan tempat mereka bekeria maka mereka akan selalu terdorong untuk bekeria lebih baik, karena menyadari apa yang bermanfaat bagi perusahaan juga bermanfaal bagl dirinya (Atmosoeprapto dalam Melinda \& Zulkarnain, 2004).

Dinas Pencegah dan Pemadam Kebakaran (DP2K) Kota Medan merupakan suatu instansi yang bergerak dalam bidang pelayanan masyarakat yang memiliki tujuan utamanya adalah melaksanakan kegiatan pencegahandan penanggulangan/pemadaman kebakaran dan bencana alam (Pernko Medan, 2005). 
Dalarn pelaksanaan tugasnya terkadang para pegawai DP2K sering mengalami hal-hal yang tidak menyenangkan, seperti ketika sedikit saja terlambat datang ke lokasi kejadian sering para pegawai DP2K ini mendapat sambutan yang buruk dari masyarakat misalnya dilempari dengan batu dan dicaci maki oleh masyarakat. Padahal keterlarnbatan mereka mungkin dikarenakan lalu lintas yang padat dan jauhnya lokasi kejadian dari kantor DP2K (Pemko Medan, 2005).

Sebagai sualu instansi yang bergerak di bidang pelayanan masyarakat, parapekerjanya rentan mengalami burnout. Jika tidak ada kejadian kebakaran, sering para pegawai DP2K ini merasa bingung harus melakukan pekerjaan yang sesuai dengan job description mereka, sehingga mereka melakukan beberapa aktivitas yang tidak sesuai dengan tugas mereka.

Jackson, dkk. (1986) mengatakan burnout muncul sebagai akibat dari tingginya tuntutan pekerjaan dan perlakuan tidak manusiawi yang diterima seseorang yang banyak terlibat sebagai service provider.

Sehubungan dengan hal tersebut di atas, peneliti merasa tertarik untuk mengetahui sejauh mana pengaruh konsep diri terhadap bumoutpada Dinas Pencegah dan Pernadam Kebakaran (DP2K) Kota Medan.

\section{Tinjauan Pustaka}

Maslach, Leatz dan Stolar (dalam Asiad \& Soetipto, 2000), menyatakan bahwa bum out pada seseorang ditandaj oleh empat kondiși, yaitu (1) kelelahan fisik (physical exhaustion), (2) kelelahan emosional (emotional exhaustion). (3) kolelahan mental (mental exhaustions, dan (4) rendahnya perasaan mampu mencapai sesuatu yang berarti dalam hidup (low of personal accomplisment.

Pines dan Aronson (dalam Sut.jpto, 2001) mengemukakan 3 dimensi dari bumout adalah:

1. Kelelahan fisik

2 Kelelahan emosional

3. Kelelahan mental

\section{ad 1. Kelelahan fisik}

Kelelahan fisik yaitu suatu kelelahan yang bersifat fisik dan energi fisik. Sakit fisik dicirikan seperti sakit kepala, demam, sakit punggung (rasa ngilu), rentan terhadap penyakit, tegang pada otot leher dan bahu, sering terkena flu, susah tidur, mual-mual, gelisah, dan perubahan kebiasaan makan. Energi fisik dicirikan seperti energi yang rendah, rasa letih yang kronis, dan ternas.

\section{ad 2. Kelelahan emosi}

Kelelahan emosi yaitu suatu kelelahan pada individu yang berhubungan dengan perasaan pribadi yang ditandai dengan rasa tidak berdaya dan depresi. Kelelahan emosi ini dicirikan antara lain rasa bosan, mudah iersinggung, sinisme, perasaan tidak menolong, ratapan yang tiada henti, tidak dapat dikontrol (suka marah), gelisah, tidak peduli terhadap tujuan, tidak peduli dengan orang lain, merasa tidak merniliki apa-apa untuk

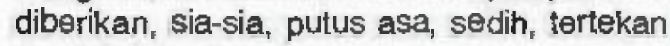
dan tidak berdaya.

\section{ad 3. Kelelahan mental}

Kelelahan mental yaitu suatu kondisi kelelahan pada indivldu yang berhubungan dengan rendahnya penghargaan diri dan depersonalisasi. Kelelahan mental ini dicirikan antara lain merasa tldak berharga, rasa bencl, rasa gagal, tidak peka, sinis, kurang simpati dengan orang lain, mempunyai sikap negatif terhadap orang lain, cendrung masa bodoh dengan dirinya, pekerjaannya dan kehidupannya, acuh tak acuh, pilih kasih, solalu menyalahkan, kurang bertoleransi terhadap orang yang ditolong, ketidakpuasan terhadap pekerjaan, konsep diri yang rendah, merasa tidak cakap, merasa tidak kompeten, dan tidak puas dengan jalan hid up.

Masclach dan Jackson (Golembiewsky, dkk., 1987) memberikan gambaran adanya tiga dimensi bumout, yaitur a) kelekahan emosional yang ditandai dengan perasaan fustrasi, putus asa, sedih, tidak berdaya, tertekan, dan ia merasa terjebak. Ditambah mudah tersinggung, dan marah tanpa alasan yang jelas. b) depersonalisasi, ditandai dengan 
menjauhnya individu dari lingkungan sosiak, apatis, tidak peduli terhadap lingkungan dan orang-orang disekitarnya. c) rendahnya penghargaan terhadap diri sendiri, yaitu individu tidak pernah merasa puas dengan hasil karyanya sendiri, merasa tidak pernah melakukan sesuatu yang bermanfaat bagi diri sendiri, maupun orang lain.

Girdino, Everly, \& Dusek (1996) merjelaskan tiga tahapan dari bumout, yaitu: Siress Arousal Energy Conservation dan Exhaustion.

\section{ad 1. Stress Arousal}

Siress arousalter diri dari respon fisiologis dan psikologis. Termasuk di dalamnya yaltu irritabilly, kecemasan yang menetap, periode dimana tekanan darah menjadi tInggi, insomnia, dan kelupaan. Dan juga mungkin mengalami ritme jantung yang tidak biasanya, masalah dalam konsentrasi, masalah saki: kepala/sakit perut dan gejala gastrointestinal yang akut. Dengan adanya dua gejala dari berbagai gejala datas blsa dikatakan individu berada d tahap satu.

\section{ad 2. Energy Conservation}

Energy conservation muncul sebagai kompensasi dari stress. Jika strategi yang dilakukan gagal dalam mengatasi masalah pada tahap satu maka konsekuensi yang mungkin muncul adalah sering terlambat datang kerja, seringnya tidak hadir, keieiahan yang berkepanjangan, menghindar dari lingkungan sosial seperti keluarga dan teman, menlngkatnya sinlsme, meningkatnya penggunaan substanși (nikotin, kafein, alkohol, dan obat-obatan terlarang), dan apatis. Dengan ad any a dua gejala dari berbagal gejala diatas bisa dikalakan individu berada di tahap dua.

\section{ad 3. Exhaustion}

Pada tahap Ini kebanyakan indivldu akhirnya merasa bahwa ada sesuatu yang salah pada dirinya. Gejalanya meliputi; kesedihan dan depresi yang kronis, masalah perut dan buang air besar yang kronis, kelelahan mental yang kronis, kelelahan fisik yang kronik, sakit kepala dan migrain yang kronis, hasrat untuk melarikan diri dari lingkungan dan bahkan ada pemikiran untuk bunuh diri. Dengan adanya dua gejala dari berbagai gejala di atas bisa dikatakan individu berada d tahap tiga.

Individu yang mengalami gejala bumout diindentifikasikan oleh Froudenberger dan Richelson (dalam Farhati \& Rosyid 1996) seperti : 1) kelelahan yang disertal keletihan. Individu sulit menerima kondisi ini karena mereka merasa bahwa selama ini tidak pernah merasa lelah walaupun aktivitas yang dilakukan sang at padat 2) lari dari kenyataan. ini merupakan alat yang digunakan individu untuk menangkal penderitaan yang dialami. Pada saat individu merasa kecewa mellhat kenyataan yang tidak sesuai dengan harapan, mereka menjadl tidak peduli terhadap permasalahan yang ada. 3) Kebosanan dan Sinisme. Mereka muial mempertanyakan makna kegiatan yang dilakukan dan muiai merasa bosan dengan kegiatan tersebut. 4) Tidak sabaran dan mudah tersinggung. Hal ini terjadi karena selama ini individu dapat melakukan segaja hal dengan cepat. Ketka mengalami kelejahan, kemampuan mereka dalam menyelesaikan sesuatu hal mulai berkurang, sehingga mereka menjadl tidak sabaran dan mudah tersinggung. 5) Merasa tidak d!hargai. Usaha yang semakin keras namiun tidak disertai dengan energi yang cul up, serta hasil yang diperoleh tidak menuaskan, menyebabkan mereka merasa tidak dihargai oleh orang lain. 6) keluhan psikosomatis. Individu cenderung mengeluh sakit kepala, ketegangan otot punggung dan gangguan flsik lalnnya. 7) penyangkalan terhadap kenyataan yang dihadapi. Penyangkalan terhadap kegagalan yang dialami dan penyangkalan terhadep ketakutan yang dirasakannya.

Bumout merupakan suatu kondisi dari reaksi terhadap harapan dan tujuan yang tidak realistis terhadap perubahan yang dinginkan. Kondisi ini mempengaruhi individu yang termotivasi dengan idealisasi yang tinggi (Stanley, 2004). Tingginyastandar keberhasilan pribadi berkaitan dengan konsep diri. 
Berdasarkan tabel 1 di atas diperoleh mean empirik skala konsep diri $X_{E}=130.84$ ) dengan $\mathrm{SD}$ empirik t0.76, dan mean hipotétik sebesar $\left(X_{\mathrm{n}}=110\right)$ dengan SD hipotetik 22 $\mathrm{Hal}$ ini menunjukkan bahwa subjek penelitian memiliki konsep diri yang lebih positif dibandingkan pada umumnya.

Tabel. 2

Deskripsi Data Penelitian Bumout

\begin{tabular}{|c|c|c|c|c|c|c|c|c|c|}
\hline \multirow{2}{*}{ Varlabel } & \multicolumn{5}{|c|}{ Stror Emplrik } & \multicolumn{4}{|c|}{ Skor hipotstk } \\
\hline & $\mathbf{N}$ & Min & $\operatorname{Max}$ & Mean & SD & $\mathrm{Mn}$ & Max & Mean & SD \\
\hline Bumbet & 85 & 58 & :02 & 74,74 & 7.45 & 38 & $\$ 52$ & 95 & 18 \\
\hline
\end{tabular}

Berdasarkan tabel 2 di alas diperoleh mean empirik skala burnout sebesar $\chi_{\mathrm{E}}=$ 74.74) dengan SD empirik 7.45 dan mean hipotetik sebesar $\left(x_{n}=95\right)$ dengan SD hipotetik 19. Hasil perbandingan antara skor mean einpirik dengan mean hipotetik menunjukkan balwa karyawan memiliki tingkat bumoutyang lebih rendah dibandingkan pada umumnya.

b. Gambaran Bumout ditinjau dari masa kerja Untuk melihat gambaran burnout berdasarkan masa kerja dapat dilihat pad a tabel. 3.

Tabel 3.

Gambaran Bumout Berdasarkan Masa Kerja

\begin{tabular}{cccc}
\hline Masa Kerja & N & Mean & Std.Deviasi \\
\hline 2 sd 10 tehun & 43 & 73.1860 & 5.76217 \\
11 sd 20 tahun & 22 & 78.1364 & 9.33144 \\
21 sd 20 taimn & 20 & 74.3500 & 7.56220 \\
\hline
\end{tabular}

Tabet 4.

Gambaran Bumout Berdasarkan Masa Kerja

\begin{tabular}{lccccc}
\hline & $\begin{array}{c}\text { Surn of } \\
\text { Squares }\end{array}$ & of & $\begin{array}{c}\text { Meen } \\
\text { siquere }\end{array}$ & F & Sig \\
\hline Betwen Groups & 360653 & 2 & $\$ 80,327$ & $3.43 \%$ & 037 \\
Within Grops & 4309.653 & 82 & 52567 & & \\
\hline Total & 4670,306 & 84 & & & \\
\hline
\end{tabular}

Berdasarkan tabel, 4 uji Anova maka diperoleh nilail $F=3.431$ dengan $p<0.05$ yang berarti ada perbedaan tingkat bumoutditinjau dari masa kerja. Hal ini mengindikasikan bahwa masa kerjamemiliki pengaruh terhadap bumout

\section{Pembahasan}

Hasil penelitian menunjukkan adanya hubungan negatif antara konsep diri dengan tingkat burnout. Hal ini menunjukkan bahwa semakin positif konsep diri seseorang, maka semakin rendah tingkat bumoutyang dialami oleh seseorang. Maslach (dalarm Sutjipto, 2001) mengatakan bahwa individu yang memiliki konsep diri rendah atau negatif lebih rentan terhadap bumout. Bumoutmerupakan hasil dari sebuah reaksi terhadap harapan dan tujuan yang tidak realistik terhadap perubahan yang diinginkan, pekerjaan yang mempunyai tuntutan emosional yang relatif konstan dengan orang lain, dan tujuan jangka panjang yang sulit dicapai, la menggambarkan bahwa karakteristik individu yang memiliki konsep diri rendah yautu tidak percaya diri dan memiliki penghargaan diri yang rendah. Mereka pada umumya dilingkupi oleh rasa takut sehingga menimbulkan sikap pasrah. Dalam bekerja, mereka tidak yakin sehingga menjadi beban kerja berlebihan yang berdampak pada terkurasnya sumber diri. Ponilaian diri yang negatit ini menyebabkan mereka lebih menitikberatkan perhatian pada kegagalan daam setiap hal sehingga menyebabkan perasaan tidak berdaya dan apatis.

Menurut Brooks dan Emmert (dalam Rakhmat, 2001) ada empat tanda orang yang memiliki konsep diri negatif. Pertama, a peka pada krittk. Individu ini sangat tidak tahan kritik yang diterimanya, dan mudah marah atau naik pitam. Bagi individu ini, koreksi sering kali dipersepsi sebagai usaha untuk menjatuhkan harga dirinya. Kedua, responsif sekali terhadap pujien. Walaupun ia mungkin berpura-pura inenghindari pujian, la tidak dapat menyembunyikan antusiasmenya pada waktu menerima pujian. Kistiga, mereka tidak pandal dan tidak sanggup mengungkapkan penghargaan alau pengakuan pada kelebihan orang lain. Keempat, individu yang konsep 
dirinya negatif, cenderung merasa tidak disenangi orang lain. la merasa tidak diperhatikan. Karena itulah ia bereaksi pad a orang lain sebagai musuh, sehingga tidak dapat melahirkan kehangatan dan keakraban persahabatan, la tidak akan pernah mempersalabkan dirinya, tetapi akan menganggap dirinya sebagai korban dari sistem sosial yang tidak beres. Kelima, bersikap pesimis terhadap kompetisi seperti terungkap dalam keengganannya untuk bersaing dengan orang lain dalam membuat prestasi. a menganggap tidak akan berdaya melawan persaingan yang merugikan dirinya.

Sebaliknya, menu nut Brooks dan Emmert (dalam Rakhmat, 2001) orang yang memiliki konsep dirl positif ditandai dengan lina hal, yaitu yakin akan kemampuan mengatasi masalah, merasa setara dengan orang lain, menerima pujian tampa rasa malu, menyadari bahwasetiap orang mempunyal berbagai perasaan, keinginan dan perilaku yang tidak seluruhnya disetujui masyarakat, serta mampu memperbaiki dirinya karena la sanggup mengungkapkan aspekaspek kepribadian yang tidak disenanginya dan berusaha mengubahnya.

Selanjutnya dari analisa tambahan dapat diperoleh data bahwa ada perbedaan tingkat burnour ditinjau dari masa kerja. Dalam penelitian terdapat perbedaan tingkat bumout pada karyawan yang memilikl masa kerja 11 sampai 20 tahun. Terjadinya bumoutpada saat pertengahan masa kerja ini disebabkan karyawan pada masa awal memasuki pekerjaan merasa terlalu bersemangat dan meletakkan harapan yang tinggi terhadap pekerjaannya yang kemudian harapan tersebut tidak dapat meroka peroleh. Hal ini sesuai dengan penelitian yang dilakukan oleh Freudenberger dan Richelson (dalam Farhati \& Rosyid, 1996) menemukan bahwa hampir semua penderita bumout pad a mulanya adalah orang-orang yang bersemangat, energik, optlmistik, dan memlliki prinsip yang kuat, serta mau bekerja keras untuk meraih prestasi, lajuga mengatakan bahwaseseorang memiliki sikap antusias dengan tujuan yang hendak dicapai pada awal kerja. Individu merasa terpanggil untuk bekerja, sehingga mereka memiliki idealisme yang tinggi. Namun stres yang dialami secara kronik menyebabkan mereka mengalami perubahan motivasi dan pad a akhirnya mereka mengalami bumout.

Menurut Pines dan Aronson (dalam Sutjipto, 2001), burnout yang dialami oleh individu yang bekerjadi soktor pelayanan sosial dalam waku yang cukup lama. Individu menghadapi tuntuan dari klien, tingkat keberhasilan dari pekerjaan yang rendah dan kurangnya penghargaan terhadap kinerja pemberi layanan. Sehingga pada akhirnya dalam jangka panjang Individu akan mengalami kelelahan karena ia berusaha memberikan sesuatu secara maksimal, namun memperoleh apresiasi yang minimal.

Selain itu, Schaufeli dan Janczur (1994), menyatakan bahwa bukan hanya tuntutan pekerjaan yang tinggl yang mempengaruhi tingkat burnout, akan tetapi juga miskinnya hal-hal yang menarik dan menantang. Pekerjaan yang tidak variatif serta pekerjaan yang tidak memberikan informasi tentang baik tidaknya usaha yang dilakukan individu merupakan faktor-faktor yang mempengaruhi tingkat bumouryang dialami okeh pemegang pekerjaan,

Peranan konsep diri terhadaptingkat bumouttelah terbukti dari hasil penelitian ini. Maka karyawan dapat menjadikan konsep diri sebagai dasar dan tolak ukur dalam meminimalisasi tingkat bumout. Adapun saran yang dapat diberikan yaitu agar pogawai selalu meningkatkan dan memperbaiki konsep dininya dengan cara lebih mengenal lagi siapa dirinya, meletakkan harapan-harapan yang sesuai dengan kemampuan yang ada padanya serta selalu menghargal drrtnya sendlri. Sehingga dengan demikian bumoutdapat dihindari. 


\section{Dafter Pus taka}

Asiad, M. \& Soetijpto, H.P. (2000). Hubungan Antara Beberapa Aspek Budaya Perusahaan Dengan Tingkat Burnout Pada Karyawan Bagian Pelayanan Publik. Jumal Psikologi, No. 2.

Berry, L.,M. (1998). Psychology at work an Introduction to Industrial \& Organizational Psychology (2nd edition). Singapore: McGraw Hill Company.

Calhoun, J.F. \&Acocella, J.R. (1995), Psikologi Tentang Penyesuaian dan Hubungan Kemanusiaan (edisi ke-3). Semarang: IKIP Semarang Press.

Farhati, F. \& Rosyid, HF. (1996). Karakteristik Pekeriaan, Dukungan Sosial, dan Tingkat Burnout Pada Non Human Sevice Corporation. Jumal Psikologi. No.1.

Gircino, DA, Everty, GS, \& Dusek, D.E (1996). Controlling stress and tension. New York : Alyn \& Bacon, Needham Heights.

Golembiewsky, R.T, Hilles, R., \& Daly, R., (1987). Some Effect of Multiple OD Intervention on Burnout and Work Site Feature. The Joumal of Applied Beharioral Science, Vol. 23, №. 3.

Jackson, S.E., Schuler, R.S., \& Schwab, R.L., (1986). Toward Understanding of Burnout Phenomenon. Joumal of Applied Psychology. Vol 77, No. 40.

Leat, C.A. \& Stolar, M. W, (1993). When
Work Gets To Be To Much. Wond Executive Digest. Vol. 14 No. 11.

Lorenz, K (2004). Job Bumout: symptoms and remedies. http:// muw,CareerBuilder.com.

Meilaratti, B. \& Zulkarnain. (2004). Konsep Diri dan Kecenderungan Pengambilan Keputusan dalam Membeli Pakaian pada Remaja Wanita. Insight, vol 2, No. 1.

Melinda, T. \& Zulkarnain. (2004). Budaya Perusahaan dan Persepsi Pengembangan Karir pada Karyawan yang Bekerja d Perusahaan Telekomurikasi. Jumal Psikologi, No.1

Pernko Medan (2005). Dinas Pencegah dan Pemadam Kebakaran Kota Medan. http:/pemkomedan.go.id/dis_ppk.htm.

Rakhınat, J. (2001). Psikologikomunikasi(ed. Revisi). Bandung: Remaja Rosdakarya.

Schaufeli, M.M \& Buunk, B.B. (1996). Handbook or Work And Health Psychology. New York: John Wiley \& Sons Lid.

Schaufeli, W.B, \& Janczur, B. (1994). BurnoutAmong Nurses : APolish Dutch Comparison. Joumal of Coss Cutural Psychology. Vol. 25. No. 7

Stanley, T.L., (2004). Burnout: a manageris Worst Nightmare. Supervision. Burlington: vol 65.

Sutjipto. (2001). Apakah Anda Mengalami Burnout. Jakarta : http:// www.depdiknas.go.id/jurnal.htm.

$\operatorname{ros} \cos c \cos c \alpha$ 